\title{
Social Media Monitoring Twitter: Mobile Brand Awareness Using the Selection Sort
}

\author{
Ali IBRAHIM ${ }^{1}$, YUSMANIARTI ${ }^{2 *}$, Zikri NURZANI $^{3}$, Alif GINA $^{4}$, Indah
} Irawati PARDEDE ${ }^{5}$, Novia RISKY ${ }^{6}$, Atik HUSNIA ${ }^{7}$

\author{
'aliibrahim@unsri.ac.id, Informatics Engineering, and Information Systems Faculty of Computer \\ Science, Universitas Sriwijaya, Indonesia \\ ${ }^{2}$ yusmaniarti8@gmail.com, Department of Accounting, Faculty of Economics, Universitas \\ Muhammadiyah Bengkulu, Indonesia \\ ${ }^{3}$ zikri@gmail.com, Nurzani Department of Information Systems Faculty of Computer Science, \\ Universitas Sriwijaya, Indonesia \\ ${ }^{4}$ alifgp@ gmail.com, Department of Information Systems Faculty of Computer Science, Universitas \\ Sriwijaya, Indonesia \\ 5Indahpardede98@yahoo.com, Department of Information Systems Faculty of Computer Science, \\ Universitas Sriwijaya, Indonesia \\ ${ }^{6}$ noviarisky12@ gmail.com, Department of Information Systems Faculty of Computer Science, Universitas \\ Sriwijaya, Indonesia \\ 7 atikhusnia98@gmail.com, Department of Information Systems Faculty of Computer Science, Universitas \\ Sriwijaya, Indonesia
}

*Corresponding author: yusmaniarti8@gmail.com

\begin{abstract}
Social media platforms not only a tool to share content and opinions, they represent a company can create business opportunities and value-added business. In fact, today people move all the real life they are present in social media. Social media or social networking sites involved in our daily lives opens the possibility to discover new information, share ideas and interact with each other. With the growing popularity of networking sites such as Twitter. Hence also the increasing competition in the business, the parties co-brand marketing competition wary public vote in a virtual space like in twitter, awareness this is becoming one of the weapons business intelligence to the mobile phone brand in finding customers and maintain customer loyalty by using the select sorting method is expected to help in achieving the goal. Of the 54 respondents $92.6 \%$ have a twitter social media, which means that many of the respondents who use social media twitter in 2019 and $31.5 \%$ of respondents opened twitter 5 to 6 hours per day and $74.1 \%$ of its've seen mobile brand ad on social media twitter and $85.2 \%$ of respondents believe that it can look for many customers and maintain customer loyalty by using social media as brand awareness Twitter., This is the insight to help businesses track the phone to a significant advantage for mobile business to improve service quality.
\end{abstract}

Keywords: monitoring, social media, selection sort algorithm 
will be converted into a useful form and stored in a database to facilitate rapid monitoring and reporting to the management of brand cell phone using data virtualization. By using social media monitoring tools, in the analysis of this sort Selection algorithm will explain the application of the algorithm in this monitoring applications. All messages collected will be converted into a useful form and stored in a database to facilitate rapid monitoring and reporting to the management of brand cell phone using data virtualization. By using social media monitoring tools, in the analysis of this sort Selection algorithm will explain the application of the algorithm in this monitoring applications.

\section{LITERATURE REVIEW}

Social media in Indonesia is already used by many users as Facebook, Twitter, Pinterest, Google, Stumbleupon, and Reddit. Research from Firefly Milward Brown described social media in Indonesia is as a tool to gain social recognition in the form of recognition and praise, also used social media to share and familiarizing themselves with others. Indonesia social media users is the second largest in the world. 35.4824 million users come from Indonesia, $85 \%$ of social media users in Indonesia aged less than 35 years, the majority come from the age group 14 to 24 years with the amount of $41 \%$ [1]. One of them is social media that has been widely used in Indonesia, namely Twitter. Twitter only has just 140 characters in all information or so-called 'tweets' [2]. According to the official website, Twitter Platform dev.twitter.com provides access to data via the Internet twitter API. Each API presents some aspects of Twitter and allows developers to build and extend their applications with a new way [3]. the news flow as in Twitter is also found to be an excellent resource for measuring or public opinion polling [4]. Hence also the competition in business is increasing, the party brand marketing co wary of competition assessment public in a virtual space like in twitter, awareness this is becoming one of the weapons business intelligence for the brand mobile phones in finding customers and maintain customer loyalty by using the select sorting is expected to help in achieving the goal. Twitter Platform providing access to data via the Internet twitter API. Each API presents some aspects of Twitter and allows developers to build and extend their applications with a new way [3]. The news flow as in Twitter is also found to be an excellent resource for measuring or public opinion polling [4]. Hence also the competition in business is increasing, the party brand marketing co wary of competition assessment public in a virtual space like in twitter, awareness is becoming one of the weapons of business intelligence for the brand mobile phones in finding customers and maintain customer loyalty by using the select sorting is 
expected to help in achieving the goal. Twitter Platform providing access to data via the Internet twitter API. Each API presents some aspects of Twitter and allows developers to build and extend their applications with a new way [3]. The news flow as in Twitter is also found to be an excellent resource for measuring or public opinion polling [4]. Hence also the competition in business is increasing, the party brand marketing co wary of competition assessment public in a virtual space like in twitter, awareness this is becoming one of the weapons business intelligence for the brand mobile phones in finding customers and maintain customer loyalty by using the select sorting is expected to help in achieving the goal. Each API presents some aspects of Twitter and allows developers to build and extend their applications with a new way [3]. The news flow as in Twitter is also found to be an excellent resource for measuring or public opinion polling [4]. Hence also the competition in business is increasing, the party brand marketing co wary of competition assessment public in a virtual space like in twitter, awareness this is becoming one of the weapons business intelligence for the brand mobile phones in finding customers and maintain customer loyalty by using the select sorting is expected to help in achieving the goal. Each API presents some aspects of Twitter and allows developers to build and extend their applications with a new way [3]. The news flow as in Twitter is also found to be an excellent resource for measuring or public opinion polling [4]. Hence also the competition in business is increasing, the party brand marketing co wary of competition assessment public in a virtual space like in twitter, awareness this is becoming one of the weapons business intelligence for the brand mobile phones in finding customers and maintain customer loyalty by using the select sorting is expected to help in achieving the goal. The news flow as in Twitter is also found to be an excellent resource for measuring or public opinion polling [4]. Hence also the competition in business is increasing, the party brand marketing co wary of competition assessment public in a virtual space like in twitter, awareness this is becoming one of the weapons business intelligence for the brand mobile phones in finding customers and maintain customer loyalty by using the select sorting is expected to help in achieving the goal. The news flow as in Twitter is also found to be an excellent resource for measuring or public opinion polling [4]. Hence also the competition in business is increasing, the party brand marketing co wary of competition assessment public in a virtual space like in twitter, awareness this is becoming one of the weapons business intelligence for the brand mobile phones in finding customers and maintain customer loyalty by using the select sorting is expected to help in achieving the goal

\section{MODELS, ANALYSIS, DESIGN AND IMPLEMENTATION}

\section{Social media}

Social Networking Media is the internet-based service that allows users to form a network that facilitates the exchange of information, best known for its ability to disseminate information or ideas that are fast enough that is often used for viral marketing [5]. Social media are often the first to break the news, only then followed by the main stream news outlets. Jakarta bombings in July 2009, in which Twitter with the news. Interestingly, it was found that even earthquakes, ranging from seismic intensity scale of 3 or more, are reported more quickly by Twitter users as opposed to the Japanese agency related [4].

\section{Twitter Monitoring}

Twitter is a micro-blogging site where users share plain text messages of 140 characters, either in person in their network, or public. The discussion is conducted by using the "@" symbol to direct messages to specific users while the symbol "\#" is used to indicate keywords to group messages in a particular conversation. Messages can be spread to other sub-networks through "re-tweet", symbolized by the "RT" and is followed by the address of the user identifier, and '\#' followed by a word that represents the hashtag [2].

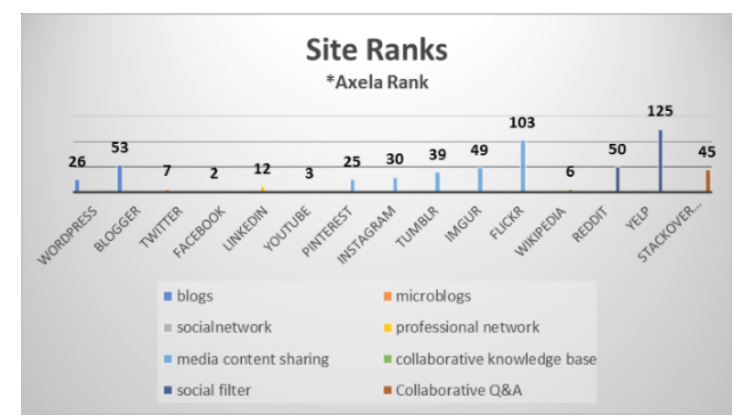

Figure. 1 Site Ranks based on AxelaRank

Using social media monitoring techniques to monitor the mention of the brand. The proposed technique consists of five main phrase: collecting data from social media, clean the data, save data to a database, search for information and reporting 


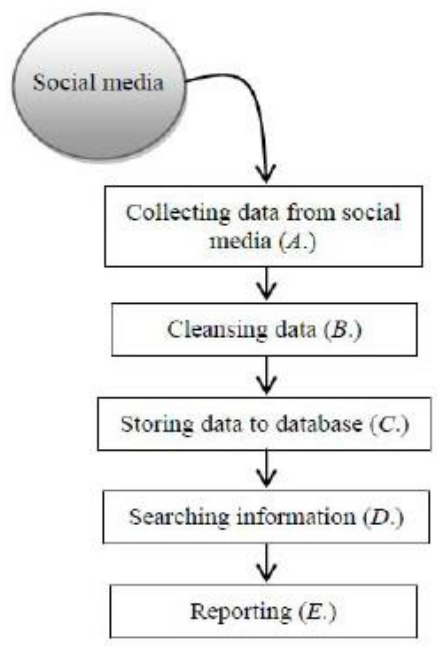

Figure 2. Workflow Monitoring Techniques

\section{Collecting data from Social Media}

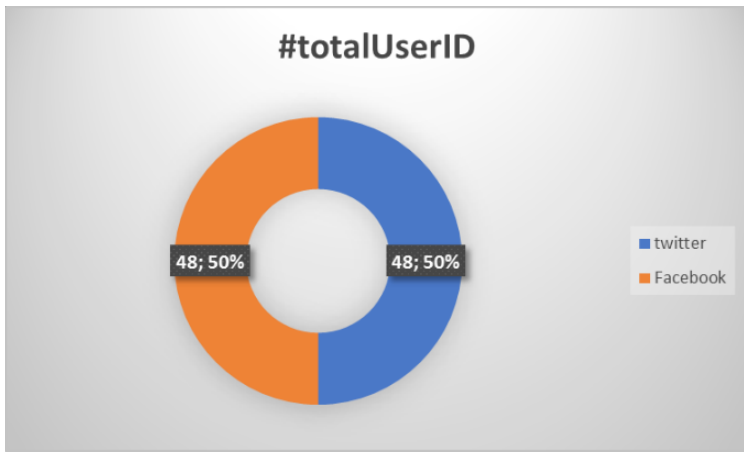

Figure 3. Participate UserID twitter and Facebook

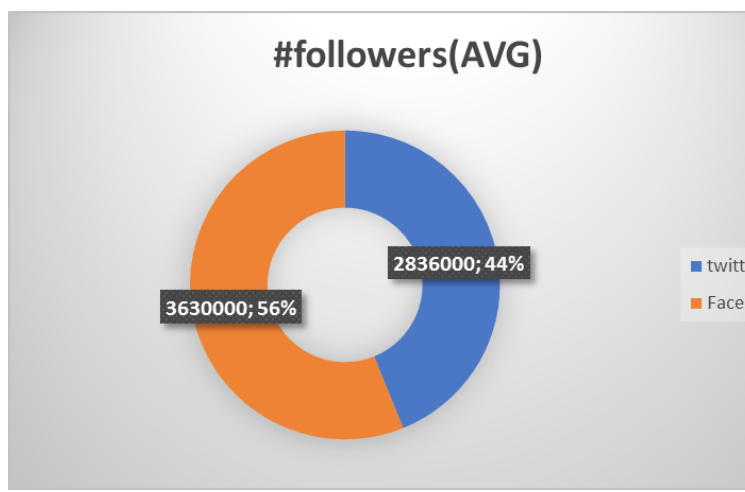

Figure 4. Average follower of participate by twitter and facebook

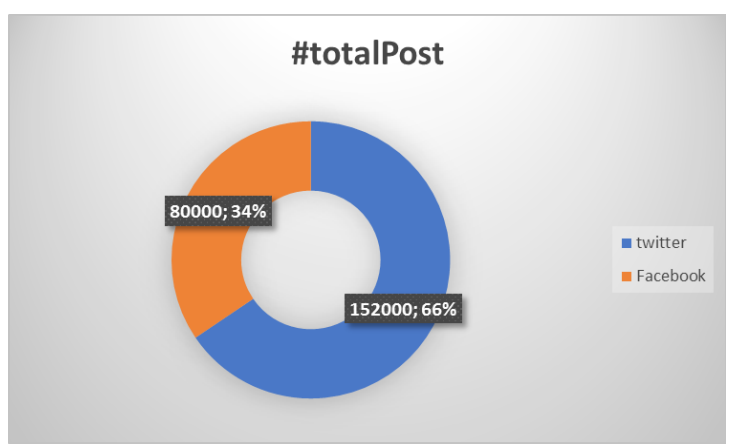

Figure. 5 total post by participate twitter and facebook

Most of the content is replicated share have been published by the news media. One of the main results of this Phase is to classify sets of news media that acts as a self-originating news [6], news providers and news consumers. The proposed technique begins by gathering conversations of the people of the right social media sources such as Twitter [7]. Input large amounts of this conversation can be considered a dynamic text that a user of a real-time or post a comment.

\section{Data Cleansing}

The proposed technique to apply the data cleansing process for involving the removal of unwanted data. The process is based on the technique of extraction and natural language processing. Only information that is meaningful for social listening techniques are extracted from the data. Tweet taken after cleaning the data is applied and the method of preparation. For example, tweet eliminate use Language Detection Library. URL and some Twitter username (@username) formed in the content and the hash tag removed [8].

\section{Storing Data to Database}

All data that is extracted will be saved into a database, used to store data because it can support large amounts of data with scalability and flexibility

Information Searching

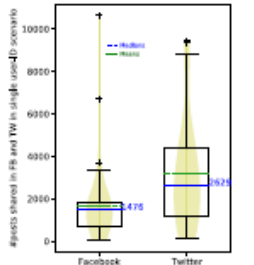

(a) \#posts-FB \& TW.

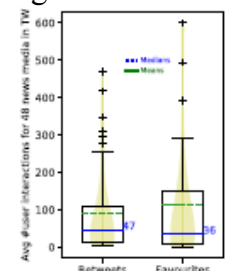

(b) Reactions-TW.

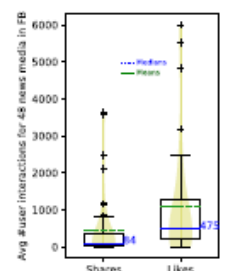

(c) Reactions-FB.

\section{Reporting}

The end of the process in the proposed technique. Very important data virtualization method is the process of collecting data from the source database information to develop a virtual view information. The output of the proposed technique will be revealed in two parts: the graph data virtualization and a list of discussion about what is being said about a brand or keyword Dashboard output will be an important tool to be handled by the management team as critical situations and to prevent their businesses spread from mouth to 
negative mouth. In addition, this tool also can track questions that may be owned by the customer in the right time and the right people.

\section{RESULTS AND DISCUSSION}

Profile of respondents were taken around 54 people with ages 18-24 years and using social media. This research was conducted in April 2019. Characteristics of these respondents may be detailed as follows:

Response diagram form. The title question: Age. Number of responses: 54 responses.

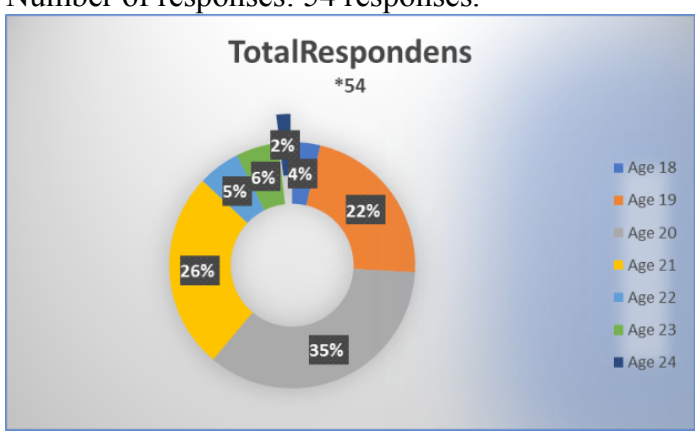

Figure 7. Percentage of Respondens

Response diagram form. The title question: Do you have a twitter account?. Number of responses: 54 responses.

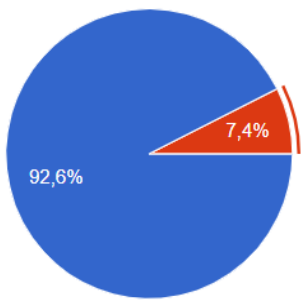

Figure 8. Respond of Respondens

Response diagram form. The title question: If you have twitter, how often do you use twitter in a day?. Number of responses: 54 responses.
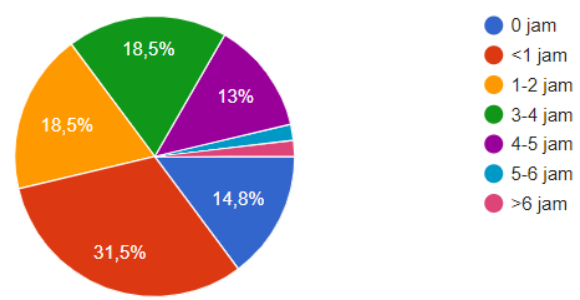

Figure 9. Prediction of using twitter in day

Response diagram form. The title question: Have you ever seen an ad on twitter mobile phone brand?. Number of responses: 54 responses.

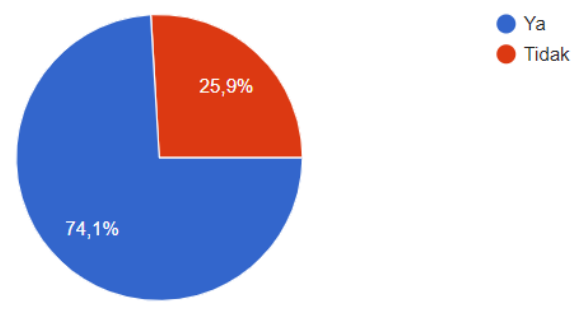

Figure 10.Ooccured advertise in twitter

Response diagram form. The title question: Do you think the public assessment of competition in virtual space like in twitter, can look for many customers and maintain customer loyalty? Number of responses: 54 responses.

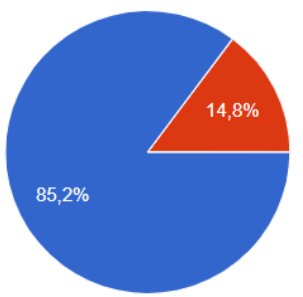

Ya

Tidak

Figure 11. Respond of assessment

Discussion Of the 54 respondents $92.6 \%$ have a twitter social media, which means that many of the respondents who use social media twitter in 2019 and $31.5 \%$ of respondents opened twitter 5 to 6 hours per day and $74.1 \%$ of it has seen mobile brand ad on social media twitter and $85.2 \%$ of respondents believe that it can look for many customers and maintain customer loyalty by using social media as brand awareness Twitter. Brand awareness according to Kotler [16] is a potential buyer's ability to recognize and remember that all of our brand is a part of a specific product category. Twitter as a social media marketing in brand awareness (brand recognition) Mobile to consumers is that through social media it is a brand of a company or organization that can and are easily recognized by the audience. Also in the promotional mix elements contained one interactive media/Internet Marketing (Internet marketing), namely the use of the internet as a marketing activity for all elements of the promotional mix. In addition to advertising, the Internet can also be used to perform other forms of promotional activities, such as sales promotions with coupons, contests, and sweepstakes online. Besides internet marketing be an effective way to communicate with consumers [18]. The use of Instagram as a social media marketing can not only increase brand recognition (brand recognition) phone, but also can improve recall for products of this Mobile brand. According to Kotler [17], Brand recall (recall the brand) is a level where the brand was mentioned by someone after mentioning the brand was first referred to as the first question about a product category or it can 
also be said recall of the brand without passing assistance because this is different from the recognition task. To achieve brand awareness at the level of the top of mind, then the plate was done in various ways, starting from doing paid promote, endorse.

\section{CONCLUSION}

Social media has become a powerful channel at this time, monitor what is mentioned on the brand and cell phone service. The proposed technique is mainly based on data collection and virtualization consists of five main phrase: collecting, cleaning, storing, searching and reporting. The proposed technique starting from the collected data from the twitter conversation. Then post, topic, comment, user id, datetime, and IP addresses will be extracted from the conversation that collected the data. The transaction will be matched against the keywords required. Finally, the decision results matches will be reported in the form of a virtual view using data virtualization techniques. From the experimental results, shows the amount mentioned in the twitter has changed every day depending on the fare promotions or news posted by the mobile phone business. It is mostly a conversation can be categorized into four main types: questions, complaints, mentions and praise. This is the insight to help businesses track the phone to a significant advantage for mobile business to improve service quality.

\section{REFERENCES}

[1] A. Ibrahim, E. S. and Z. Adetya, "Analysis of weakness of data validation from social CRM," in Proceedings of 2017 International Conference on Data and Software Engineering, ICoDSE 2017, Palembang, 2017.

[2] W. Setiawan, "Era Digital dan Tantangannya," Semin. Nas. Pendidik. 2017, 2017.

[3] A. P. Sujana, "Memanfaatkan Big Data untuk Mendeteksi Emosi," KomputikaJurnal Tek. Komput. Unikom, 2013.

[4] G. N. A. Lesmana, "Analysis of Twitter's Social Media Effects on Brand Attachment Formation,”. Indonesia., 2012.

[5] I. Prisgunanto, "Pengaruh Sosial Media Terhadap Tingkat The Effect Of Social Media On Confidence Level Associate Students," J. Penelit. Komun. dan Opini Publik, 2015.
[6] M. Setiawati, "Influence of Social Media on Consumer Purchase Interest,"., 2015.

[7] M. Auliya, Y. Watequlis, and I. F. R, "Employee Performance Assessment Application Using the Smart Method (Simple Multi-Attribute Rating Technique), J. Inform. Polinema, 2015.

[8] P. Uimonen, Internet and Social Media: Anthropological Aspects, Second Edi., vol. 12, no. August 2008. Elsevier, 2015.

[9] R. L. Angga Ginanjar Mabrur, "Application of Data Mining to Predict the Study Program of Computer Science and Information Technology Journal ( KOMPUTA )," J. Komput. dan Inform., vol. 1, pp. 53-57, 2012.

[10] A. S. Honggowibowo, D. Nugraheny, P., "Selection Sort Algorithm on Social Media Education,” pp. 51-58, 2016.

[[11] D. Jatikusumo, H. H. H, and W. Usino, "Securing Official Account Twitter Using Social Media Management System,"2015.

[12] N. R. Fatahillah, "Implementation Of Naive Bayes Classifier Algorithm On Social Media ( Twitter ) To The Teaching Of Indonesian Hate Speech," pp. 128-131, 2017.

[13] M. D. Sykora, T. W. Jackson, A. O. Brien, and S. Elayan, "National Security and Social Media Monitoring,"2013.

[14] M. D. Sykora, T. W. Jackson, A. O. Brien, and S. Elayan, "National Security and Social Media Monitoring,"2013.

[15] E. Benkhelifa and T. Welsh, “A cloud enabled social media monitoring platform for events detection and prediction," 2013 8th Int. Conf. Internet Technol. Secur. Trans. ICITST 2013, pp. 142-148, 2013.

[16] P. Rajapaksha, R. Farahbakhsh, N. Crespi, and B. Defude, "Inspecting interactions: Online news media synergies in social media," Proc. 2018 IEEE/ACM Int. Conf. Adv. Soc. Networks Anal. Mining, ASONAM 2018, pp. 535-539, 2018.

[17] T. Chumwatana and I. Chuaychoo, "Using social media listening technique for monitoring people's mentions from social 
Process. Networking, WiSPNET 2016, pp. 1917-1920, 2016. media: case study of Thai airline industry," 2017 2nd Int. Conf. Knowl. Eng. Appl. ICKEA 2017, vol. 2017-January, pp. 103106, 2017.

[18] P. B. Dastanwala and V. Patel, “A review on social audience identification on twitter using text mining methods," Proc. 2016 IEEE Int. Conf. Wirel. Commun. Signal 